\title{
豊羽鉱打
}

\section{Toyoha Mine}

\section{1. 緒言}

位置 : 豊羽鉱山は札幌市定山渓に位置し, 札幌市の南 西の方向，豊平川およびその支流白井川を遡ること 42.7 $\mathrm{km}$ の地点にあり,その途中 $14 \mathrm{~km}$ のこころに石山選鉱場 がある。国鉄札幌駅前から定鉄バス豊羽本山行きで定山 渓温泉を経て 1 時間 30 分で本山事務所に達する。冬期の 交通も全線ブルドーザおよびグレーダで除雪し確保され ている。本山事務所は海拔 $550 \mathrm{~m}$ の地点にあり，北に朝 里岳 $(1,281)$, 東に天狗岳 $(1,155)$, 南に長尾山 $(1,203)$, 無意根山 $(1,460)$ をひかえ，支笏洞爺国立公園の 北部 に位置する。地理的に気候は鉱山操業にかなりの影響が あり，11月上旬より降雪をみ， 5 月上旬まで全山白一色 に覆われる。極寒には積雪 $3 \mathrm{~m}$ 以上に達し, 気温も $-20^{\circ} \mathrm{C}$ に下がることもある。 5 月は新緑，10月は紅葉となり原 始林はすばらしい。

沿革：当鉱山発見の年代法明らかでない。明治初年米 国鉱山技師 P. C. Lyman が黒田清隆開拓長官の依たく で地質調査を行なつている。明治40年武田某が探鉱に着 手し，その後大正 3 年には久原鉱業が鉱業権を買受け豊 羽鉱山と命名して開発し，翌年に銀を対象とした乾式製 錬所を水松沢に設置して操業を始めたが，欧州大戦後の 不況のため大正11年操業を中止した。昭和 10 年久原鉱業 の後身である日本鉱業が再開し，逐年規模を拡大，こと に第 2 次世界大戦による非常増産の要請に応えて昭和 17 年には選鉱処理能力を月 $25,000 \mathrm{t}$ に増強したが，同19年 9 月白井川河床が陥没浸水, 坑内が水没し操業中止のや むなきに至つた。終戦後国内食糧増産対策の一環として 硫化鉱の産出，また産業復興上の基礎物資として，鉛・ 亜鉛の重要性が認識され再開の途が開かれ，昭和 22 年 10 月道内官公各界による豊羽鉣山復興委員会が結成され， 同25年 6 月日本鉣業より事業の一切を継承した豊羽鉱山 株式会社が設立された。全山一致意欲さかんに着々復興 計画を完遂し，また当山の鉱床特性に適応する機械化計 画も逐次実施され，生産量は年々増大し 36 年 9 月には $20,000 \mathrm{t}$ を産出，37年 4 月日本鉱業に合併し，現在注月 産35,000 t 出鉱と急速な発展をとげ，さらに生産規模の

* 日本㪘業株式会社豊羽鉱業所
正会員飯 村 温 ${ }^{*}$

拡大が計画されている状況である。

現況：現況の概要在第 1,2 表に示す。（昭和 42 年 3 月 実績)

第 1 表 粗鉱量と出鉱品位

第 2 表 従業員(鉱山部一鉱

\begin{tabular}{|c|c|c|c|}
\hline \multirow{2}{*}{$\begin{array}{c}\text { 粗 鉱 量 } \\
(\mathrm{t})\end{array}$} & \multicolumn{2}{|c|}{ 品 位 } & $\%$ \\
\hline & 銛 & 亜銛 & 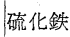 \\
\hline 31 & & & \\
\hline 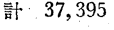 & & & \\
\hline
\end{tabular}
床探查，採鉱・選鉱部門)

\section{2. 地質鉱床の概要}

当鉱山付近の地質は主として新第三紀中新世の豊羽層 とこれを覆つて発達する湯の沢層, さらにこれらの上部 は第四紀の活動である両輝石安山岩熔岩で被覆されてい る。豊羽層は上部が変朽安山岩の熔岩, 下部は数種の堆 積岩よりなつている。変朽安山岩熔岩は火山岩組織を示 すものと角䃯岩質のものとがあり，下部の堆積岩層は黒 色頁岩を主とし漸次上部では凝灰質頁岩および砂岩に移 化し，また下部では䃋岩を夾在している。

湯の沢層は豊羽層を覆つて基底に愿い礫岩を伴ら酸性 の凝灰岩，砂岩および頁岩よりなるが全体的に酸性火山 活動により代表されるものである。このほか本山鉱床付 近には岩脈状に発達する数種の火成岩が認められ，地表 に分布する変朽安山岩熔岩忙内において岩脈として広 く分布し，また酸性火成岩として石英斑岩，石英粗面岩 が認められるが石英斑岩は本山鉱床下底部に発達してい る。当鉱山の鉱床は豊羽層を母岩とし，その裂力に胚胎 した熱水性鉱脈型鉱床である。構成鉱物は閃亜鉛鉱，方 鉛鉱, 黄鉄鉱, 菱マンガン鉱を主とし, このほか磁鉄鉱, 赤鉄鉱，磁硫鉄鉱，銀鉣物，黄銅鉣および翬安鈗などの 鉱物を伴う。鈗床は北より胆振, 長門, 本山, 大江沢, 通洞および湯の沢の各鉱床带に分類され，これらのらち 開発の最も進んでいるのは本山鉱床帯で，長門，通洞お よび大江沢の鉱床带は, 現在探鉱中で今後の開発に期待 しているものである。本山鉱床は東西系の但馬銿および 播磨銿を中心とし，東西走向延長 $2,000 \mathrm{~m}$ 以上に達する 大鉱床で, 最大脈幅 $20 \mathrm{~m}$ に達するものである。

このほか東西系として備前銿，新備前銿などの鉱床が 


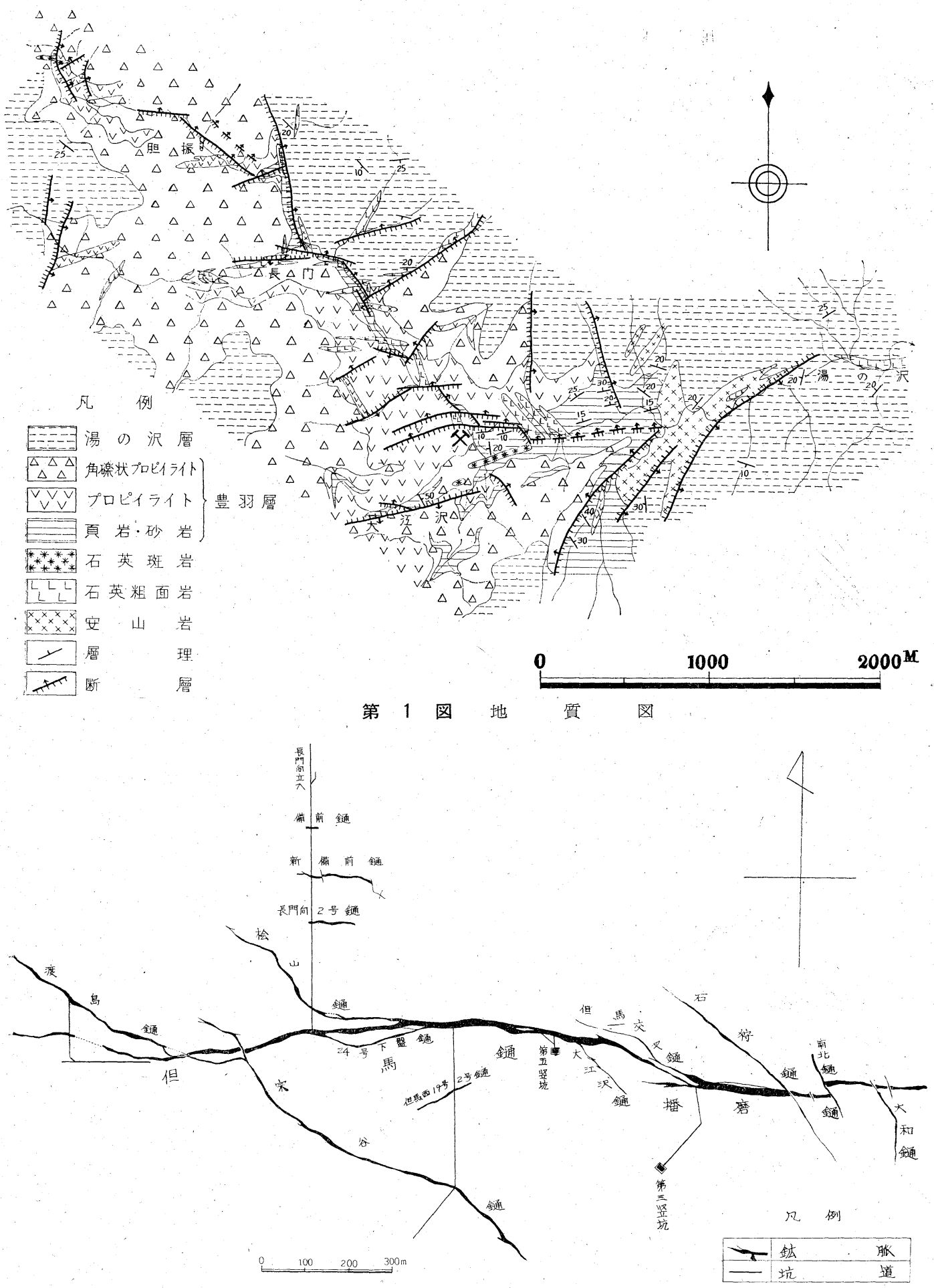

第2 図 $150 \mathrm{~mL}$ 鉱床図

認められ，またこれら東西系鉱床に斜交する NW-S E 系の宗谷銿，渡島銿，桧山銿，石狩銿および南北銿など の鉱床が開発されているが，これらの鉱脈は本山鉱床付 近の豊羽層中に認められる NE-S W 方向の軸を有する
波状褔曲で表現される褔曲運動により誘発され形成され た東西系の剪断裂力と NW-S E 方向の張力裂力に罘胎 しているものと考えている。 


\section{3. 採掘法}

採掘法の变せんおよびその採用の理由 : 昭和17年から 19年までと 26 年から 27 年までの期間は主としてシニリン ケージ採掘法であつたが，当時は主として播磨銿を採掘 の対象としていたのでつぎのような問題点があり 28 年以 降は充垻式水平段欠法に切り替えた。

イ、地表等よりの浸透水が多く鉱石の酸化が著しい。

口. 上下盤に著しく発達した石目が存在しかつ含水粘 土を伴い軟弱なため崩落ズリの混入による品位の低下。

․ 天盤の鉱石が平目状に剶離しやすく，上下盤の崩 落とあわせて切羽の維持が円滑にいかない。

二. 破研鉱石が大塊を生じやす漏斗抜取りに困難を きたす,などであつた。

現在の採掘法: 充㙗式水平段欠法 (昭和 37 年より一部 にシュリンケージ法を採用した)

(1) 準 備

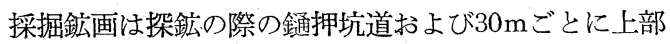
銿押坑道に貫通した掘上立坑を基準とし，走向方向に60 $\mathrm{m}$, 垂直方向に30 25m の区画を 1 切羽として設定する。

また銿押坑道と並行してあらかじめ鈗脈の下盤側 7 $10 \mathrm{~m}$ の母岩中に下盤切替坑道と, これと銿押坑道を $30 \mathrm{~m}$ ごとに結ぶ目抜立入を掘さくする。採掘準備にあたつて は，まず銿押坑道の下盤側に目抜立入を基準として $10 \mathrm{~m}$ ごとに $5 \mathrm{~m}$ の鉱井を掘上げ，この鉱井を基準にして銿押 坑道の天盤に $3 \mathrm{~m}$ の竜頭を残して中段銿押を掘進して各

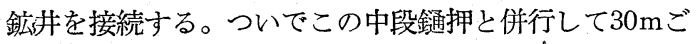

との探鉱掘上り立坑の中間に中段から上部坑道までの掘 上り立坑を掘さくして採掘準備を完了する（ただし脈幅 $5 \mathrm{~m}$ 以下の切羽には掘上りは掘さくしない)。

（2）採掘および充塡要領（第 3 図参照）

最初に上部銿押と探鉣時の掘上立坑 A との貫通個所に スラッシャを設置し, 掘上立坑Aをロープウエイとして ワイヤロープを中段地並に誘導し，バケットを取り付け る。つぎに中段地並でバケットの搔込み状況をみながら 遠隔操作で起研鉱石を鉱井に搔込みできるよう，遠隔操 作用キャップタイヤコードをスラッシャから掘上立坑 $\mathrm{A}$ を経由して中段地並に下げる。第 1 段目の掘さくは中段 坑道側壁から鉱脈上盤までの追切掘さくである。A立坑 から B立坑の方向に追切を行なら。追切が走向方向に 20 $\mathrm{m}$ 以上終了して起砕鈗石を $\mathrm{b}$ の鉱井に搔込みが可能にな つたとき $\mathrm{A}$ 鉱井を中段地並から高さ約 $2 \mathrm{~m}$ 延長する。ま た $\mathrm{A}$ 立坑の上に設置したスラッシャを $\mathrm{B}$ 立坑の上に移設 し，B立坑をロープウエイにしてスラッシングの段取を する。それから鉱石を，充壝物がズリの場合はその両方 をスラッシングする。スライム充壃の場合は平行してス ライム流送を行ない，起碎鉱石は b 立坑溞込まれる。 したがつて充荟端と切羽引立とは常に約 $20 \mathrm{~m}$ の距離を保 ちながら追いかけ充填を行ならことになる。このように してE立坑までの追切り作業および充填作業が終了する とつぎに第 2 段目の段欠作業に入る。要領は第 1 段目の 場合と全く同じである。こうして順次上部坑道地並まで 採掘する。なお追切り，採掘ともに採掘加背高は $2.5 \mathrm{~m}$ を基準にしている。
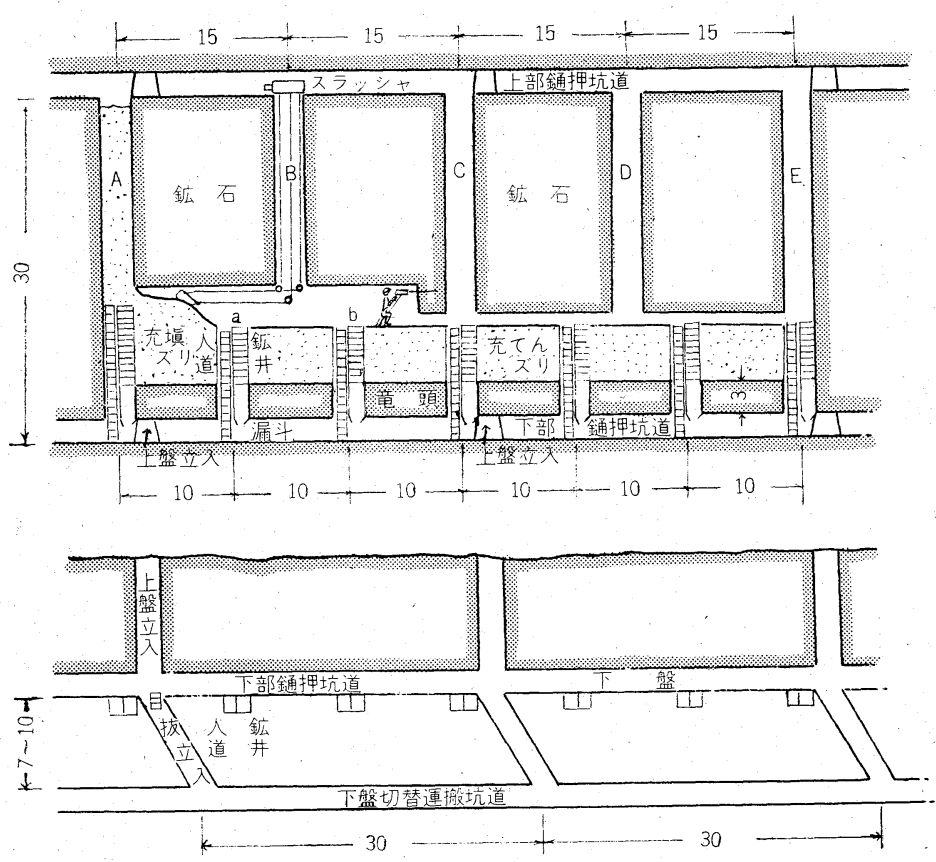

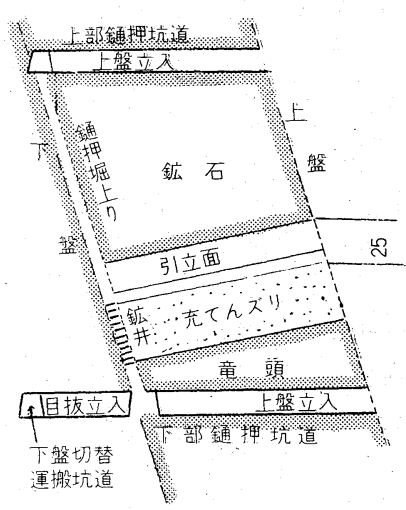

第 3 図充埧式水平段欠法 
(1)

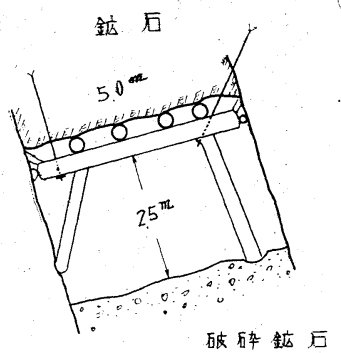

(4)

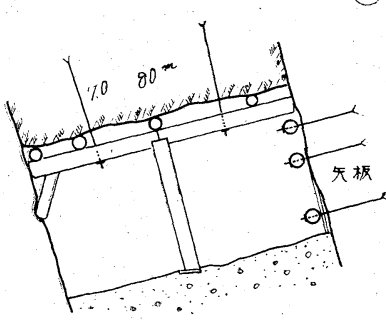

(3) 切羽の人員配置

さく岩員 1 名, スラッシャ員 1 名, 漏斗拔員 1 名のク ルー作業である。

\section{(4) さく岩作業}

さく岩作業はレッグドリルを使用して上下約 $70 \mathrm{~cm}$ 左 右約 $60 \mathrm{~cm}$ のさく孔配置で, 平行水平さく孔を約 $2 \mathrm{~m}$ 行 なう。装薬量は平均 $500 \mathrm{~g} /$ 孔である。雷管は上盤の軟弱 な所では主としてD.S その他の所では M.S を用いてい る。爆薬は 3 号桐, A N-F O のほか岩盤温度の高い個 所には榎ダイナマイトを用いている。さく岩機はＡＳＤ 322 を主とし, ロッドは $\mathrm{CR}_{2} 22 \mathrm{~mm}$ 六角中空鋼の完成テ 一パーのものを使用し、ビットはトーアロイ,または夕 ンガロイの $38 \mathrm{~mm} \phi$ クロスビットを使用している。

\section{(5) 運 搬}

起砕された鉱石は 2 次破砕等を行なつてスラッシング するが普通さく孔足場を最初にスラッシングして，さく

第 3 表 採掘法別出鉱量扰よび切羽数 (42年3月)

\begin{tabular}{|c|c|c|c|}
\hline 採掘法の種類 & 出铒 量 & 出鉣比率 & 切 羽 数 \\
\hline $\begin{array}{c}\text { 充填式水平段欠法 } \\
\text { シュジージ法 } \\
\text { 計 }\end{array}$ & $\begin{array}{r}28,090 \\
3,180 \\
31,270\end{array}$ & $\begin{array}{r}89.8 \\
10.2 \\
100.0\end{array}$ & $\begin{array}{r}36 \\
5 \\
41\end{array}$ \\
\hline
\end{tabular}

第 4 表 開探鉱出鉱量括よび試錐延長 (42年 3 月)

\begin{tabular}{|c|c|c|c|c|c|}
\hline \multirow{2}{*}{$\begin{array}{c}\text { 試 錐延長 } \\
(\mathrm{m})\end{array}$} & \multirow{2}{*}{$\begin{array}{c}\text { 探 鉱延長 } \\
(\mathrm{m})\end{array}$} & 出 & 鉱 & 量 & $(t)$ \\
\hline & & 開探鉱 & 採 & 鉱 & 訫 \\
\hline 336.5 & 602.3 & 6,125 & & & 37,395 \\
\hline
\end{tabular}

(3)

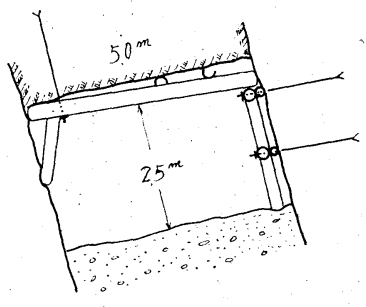

(6)

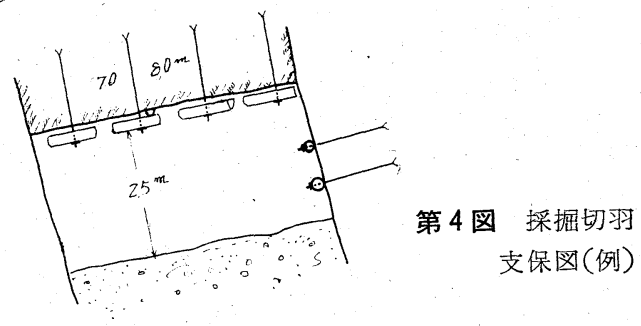

孔作業を開始してから併行的に鉱井までスラッシングす る。スラッシャは脈幅 7 $8 \mathrm{~m}$ までの切羽には $10 \mathrm{HP} れ$ 以上は201Pの各 3 胴電動型のものを使用している。採掘

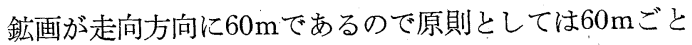
に配置している。バケットは $10 \mathrm{PP}$ 用には $36^{\prime \prime}, 20 \mathrm{PP}$ 用は 42 " のものを，ワイヤロープは $10 ， 20 \mathrm{P}$ ともに $14 \mathrm{~mm} \phi$ 19 本 6 撚のものを使用している。

鉱井に搔込まれた鉱石は下部鐥押坑道に設けてある漏 斗から抜き取り，切替運搬坑道まで，または鉱石大立坑

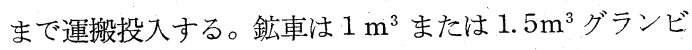
一カーを用い列車編成をし蓄電池機関車 $(1.5 \sim 4 \mathrm{t})$ に よつて集約鉄砲をで運搬される。

(6) 支 保

上盤のうち粘土石目等により軟弱層になつている個 所，緩傾斜のため崩壊しやすい上盤および支脈が切羽の 上盤近くにある場合には片留または三留で支保する。ま た層状の亀裂のために剝離しやすい上盤に対してはルー フボルトによる支保を行なら。ルーフボルトは長さ 1.5 $\sim 2 \mathrm{~m}, 19 \mathrm{~mm} \phi$ 丸鋼の楔式で要所に打込み岩盤とルーフ ボルトの座金の間に長さ約 $50 \mathrm{~cm}$ ，直径約 $15 \mathrm{~cm}$ ほどの 坑木を入れ,ルーフボルトを通して締めつけルーフ孔の 左右 $50 \mathrm{~cm}$ の範囲を同時に支保する場合もある。またル 一フボルトと坑木を組み合せた支保をする場合もある。 堅硬な上盤に対しては無支保である(第4 図参照)。

その他切羽内作業の天盤保持のため $1.5^{\prime \prime}$ 径パイプ支

第 5 表 採掘法別工程原単位拈よび直接採掘・採鉱費 （41年 4 月〜 42年 3 月）

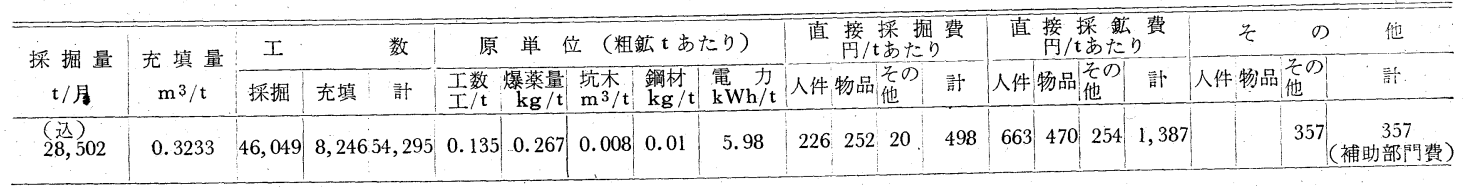


柱を使用している。

\section{4. 運 搬}

鉱石: 鉱体が西部と下部の方向に発展するので運搬系 統の集約合理化を目的として，第 5 立坑を鉱体のほぼ中 央部に開さく，昭和36年10月に完成して操業している。 この立坑により深部開発が著しく促進された。運搬系統 は各坑道の鉱石を上部は $150 \mathrm{~mL}$ L、下部は $250 \mathrm{~mL}$ Lそ

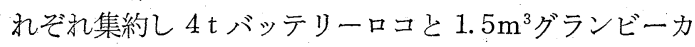
-10車の列車編成で第 5 立坑オアビンに運搬し投入す る。オアビンから抜かれた鉱石は立坑破砕の $55 \mathrm{~kW}$ クラ

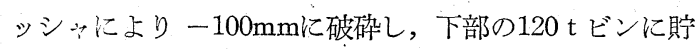
鉱し,ここからパンコンベヤにより計量され $4 \mathrm{t}$ ホッパ に入れられる。立坑内の $4 \mathrm{t}$ 底開式スキップが積込場に 到着すると一連の自動積込装置が作動して積込みが終

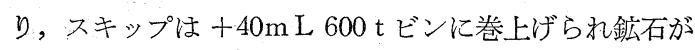
投入される。この装置は全く自動式で巻上機運転員を除 き無人で積卸しを行子つている。+40m Lでは坑外粗砕 場まで幅 $24^{\prime \prime}$ ，全長 $400 \mathrm{~m}$ のベルトコンベヤで輸送してい る。除雪および資材運搬の関係で坑外 No. 2 ベルト. $60 \mathrm{~m}$

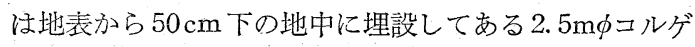
一トパイプ内に布設し，またNo. 3 ベルト $100 \mathrm{~m}$ はパイ プバウス内に布設, 高架輸送路としている。第 5 立坑の 機械設備の主仕様は第 6 表のとおりである。

ズリ: $225 \mathrm{~m} \mathrm{~L}$ 以上の探開鉱ズリは $0.6,1,1.5 \mathrm{~m}^{3}$ の 鉱車で，手押またはバッテリーロコで各レベル以下の採 掘切羽人充垻するが， $225 \mathrm{~mL}$ 以下のズリは $350 \mathrm{~mL}$ 第 5 立坑付近に設けてある集約ズリビンに投入し， $350 \mathrm{~mL}$ で $0.6 \mathrm{~m}^{3}$ 鉱車に積込み第 5 立坑のマンリフトケージに上 段市段各1車ずつ積込んで巻上げ，必要なレベルで抜き 出し充填する。

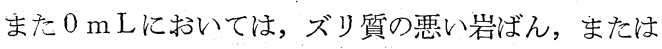
充填ズり量が必要量以上になつた場合は粗砕場にあるズ リビンに投入し坑外に処理する。手選ズリは坑内に逆送 し充境材に利用している。

人員 : 人員の昇降は第 3 立坑化設置する75H（塔乘人 員 8 名, $+40 \sim 150 \mathrm{~mL}$ の間) と第 5 立坑 (塔乗人員上 下段各10名計 20 名， $+40 \sim 350 \mathrm{~mL}$ の間）の 2 系統のマ ンリフトケージで行なつている。信号員を專属に配置し 第 3 立坑は 1 方のみ使用し, 第 5 立坑は 24 時間運転して いるがズリ運搬，材料運搬などの関倸で時間制限をして いる。マンリフトケージのほかに一連の非常人道も設け ている。

材料：主として第5 立坑のマンリフトケージを利用し ている。このマンリフトケージは材料運搬のとき上下段 の中仕切りを取りはずして積込み，形状の大きいものは ケージの下に吊る。 1 日の運搬時間は 1 方 2 時間， 2 方
5 時間, 計 7 時間程度で必要なレベルのプラットに運搬 する。各プラットに置かれた材料は各区内ごとに材料台 車で当日または翌日，材料置場に運搬される。

\section{5. 通気, 排水, 照明, 保安その他}

通気: 通気量は自然通気で十分であるが当山の坑内温 度は極めて高いので, 坑内冷却を主目的として東通気立 坑に 75Hのファン, 西35号斜坑に 500Pのファンを設置 し, 東系統で約 $1,500 \mathrm{~m}^{3} / \mathrm{min}$, 西系統で約 $7,500 \mathrm{~m}^{3} / \mathrm{min}$ を排気させている。入気量は約 $8,000 \mathrm{~m}^{3} / \mathrm{min}$ である。

排水：坑内水は年間平均約 $3 \mathrm{~m}^{3} / \mathrm{min}$ である。これを 東系統( 約 $1.5 \mathrm{~m}^{3} / \mathrm{min}$ ), 西系統 (約 $1.5 \mathrm{~m}^{3} / \mathrm{min}$ ) に分け 東系統は第 2 立坑，第 3 立坑㧍よび第 1 立坑に配管し, 西系統は第 5 立坑配管し，350，300，250，200m Lか ら $90 \mathrm{~mL}$ 地並へボンプアップし東系統は $0 \mathrm{~mL}$, 西系統 は $+40 \mathrm{~mL}$ 一揚水して坑外沈殿池へ流し石灰処理をし た後排水している。酸性が非常に強いためステンレスボ ンプを使用，自動運転を採用している。そのほか $350 \mathrm{~mL}$ より温泉水を約 $700 \mathrm{~m}^{3} / \mathrm{min}$ 程度, 直接坑外に排出してい る。

照明：坑内主要設備個所には電灯および螢光灯を設 け，スラッシャ切羽には $200 W$ 投光器を使用している。 また坑内員㤬呈キャップランプを使用している。

保安: 保安成績は従業員の上下一致協力により向上し つつ制り，災害日数の記録も漸次更新されている。当山 の特殊性としては玾内温度が非常に高いことであり,乙 たがつて坑内環境は極めて悪く, 共通的保安対策に伴う 教育管理改善等に務めているほかに, 坑内環境の整備す なわち坑内温度（稼行切羽温度）を低下させるために積 極的に改善を計つているのが保安対策の他山との相異点 である。

\section{6. 問題点と将来の計画}

当山の特殊性として坑内温度が非常に高いことであ る。したがつてこれに付随して発生する問題点が主であ る。

実労働時閒と工程の関係，使用する機器具の制限，等 々，列記するのにあまりがある。したがつて将来の計画 としては，いかに悪環境を改善するかにあるのでその方 法としては, 通気改善, 冷水利用の冷却, 温泉の排出な ぞのほかに，

機械化と技術の向上を計り

1 切羽あたりの出鉱量の増加,

1 切羽あたりの掘進延長増加等により切羽を集約する これによつて集中的に泠却して稼行切羽の環境改善を し，これにもとづく工程の上昇, すなわち、コストの低 減を計るべく計画し，遂行している。 


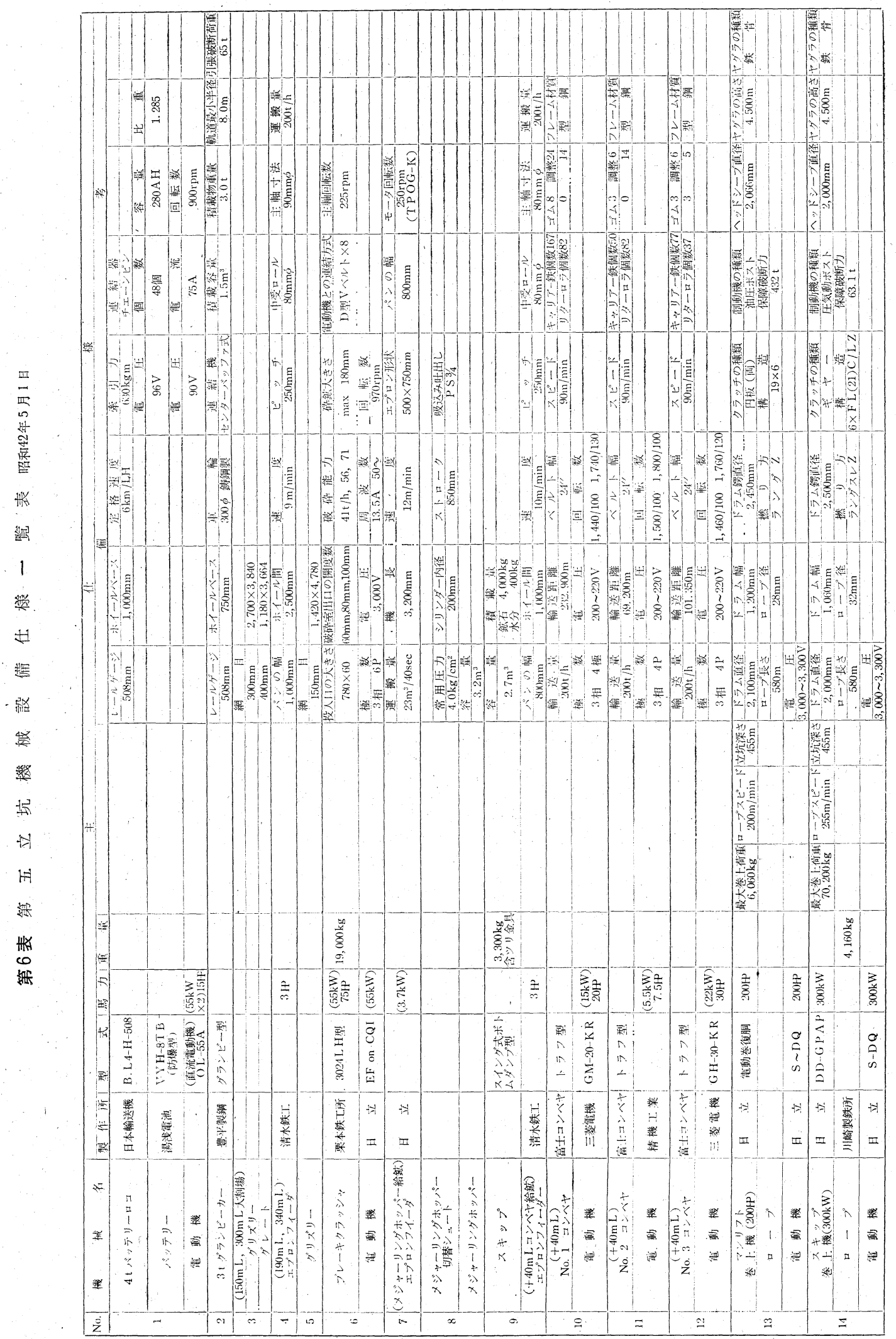




\section{7. 過去10年間の年間粗鉱量, 平均品位およ び能率の推移（坑内, 全山）(第 7 表,}

第 5 図参照)

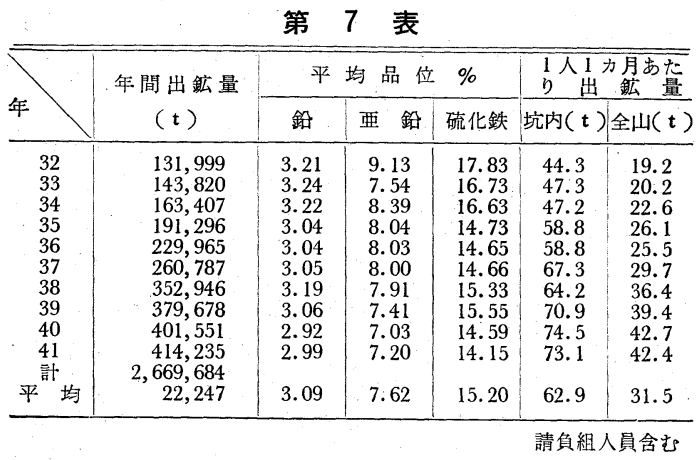

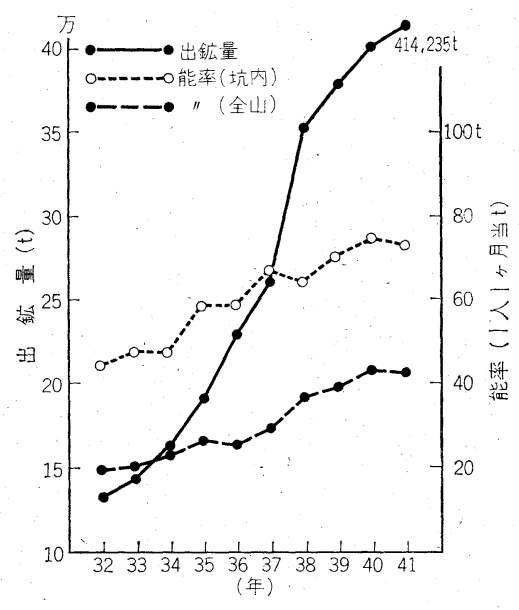

第 5 図

\section{尾太鉱山}

\section{Oppu Mine}

\section{1. 緒。言}

位置 : 青森県中津軽郡西目屋村砂子瀬

弘前市よりバスで 1 時間 30 分, $28 \mathrm{~km}$

沿革： 807 年 (大同 2 年) 発見といわれる。

1598年（慶長 3 年）津軽藩時代に盛儿に稼行された。 1898年（明治初年）維新の変動に際し休山となる。

1931年（昭和 6 年) 東京の高木某が本鉱山の総合開発 を企図し，付近の鉱区の統合を行なつた。

1935 1942年（昭和10年 17年）粗鉱 $3,000 \mathrm{t}$,銅精鉱 $70 \mathrm{t}$ 産出, 発盛, 尾去沢, 小坂に売鉱した。

1935 1950年（昭和18年～25年），経営不振のため鉱業 権は帝国鉱発，大正製薬，新興産金，日新興業， 津軽鈗業，滰の沢銅山，東北金山などを転々し た。

1950年（昭和25年）赤山鉱山株式会社が買収, 開発に 着手した。

1952年（昭和27年）尾富鉱業株式会社設立に伴い買 収，大切坑立入にて優勢な尾太本銿に着脈し た。

1954年（昭和 29 年） $3,750 \mathrm{t} /$ 月 处理の選釷場完成。以 来選鉱場および付帯設備を逐次増強。

1960年（昭和35年）下 7 坑選鉱場完成。月産粗鉱量 $13,000 \mathrm{t}$ となる。
田 $\underset{\text { Saburo TANAKA }}{\text { 三 }}$ 郎*

1964年（昭和39年）下 7 坑選鉙場重選設備完成。月産 20,000 t となる。

本山合宿を廃止し, バス通勤となる。

1967年（昭和 42 年） 4 月より月産粗鉣 $23,200 \mathrm{t}$ とな る。

現状：（昭和 42 年 3 月実績）

第1 表 粗鉱量と出鉱品位

\begin{tabular}{|c|c|c|c|}
\hline \multirow{2}{*}{$\begin{array}{c}\text { 粗 鉱 量 } \\
\text { ( } \mathrm{t})\end{array}$} & \multicolumn{2}{|l|}{ 品 } & 位 \\
\hline & $\begin{array}{l}\mathrm{Cu} \\
\%\end{array}$ & $\begin{array}{l}\mathrm{p}_{\mathrm{b}} \\
\%\end{array}$ & $\begin{array}{l}\mathrm{Zn} \\
\%\end{array}$ \\
\hline 23,741 & 0.52 & 1.14 & 3.31 \\
\hline
\end{tabular}

第2表 従 業 員

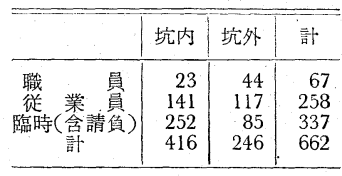

\section{2. 地質・鉱 床}

本地域の地質は基盤とされている先第三系およびこれ を貫く花崗閃緑岩が局部的に小露出している。これらを 被覆して第三紀中新世の凝灰岩類が広く分布しており， これら堆積岩類を下部から, 本山層, 小湯の沢層, 尾太 岳層の三層に分けている。第三紀の火成岩としては, 安 山岩, 玢岩, 石英粗面岩などがある。

鈗床としては，銅，鉛，亜鉛鉱床が普遍的であるが， その他金銀鉱床として寒沢鉱床, 銅鉱床として滝の沢鉱 床がある。寒沢, 滝の沢鉱床は往時稼行されたこともあ るが，小規模な鉱床で単独稼行は困難である。現在稼行 中の尾太鉙床は本山層と尾太岳層との不整合面付近に生 成された剪断裂力に生じた鉙脈鉱床で，尾太本銿および 